\title{
THE CO-ADSORPTION OF METHANE AND CARBON DIOXIDE ON CATALYSTS
}

\author{
TÍMEA SÜLI-ZAKAR \\ Institute of Crop Production and Environment Protection \\ University of Szeged \\ Andrássy út 15, 6800 Hódmezővásárhely, Hungary \\ sulizakartimea@mgk.u-szeged.hu
}

\begin{abstract}
In the elucidation of the reaction mechanism of a catalytic process it is important to establish the reaction intermediates and their possible role in the reaction. In most cases, however, this is not an easy task as a real reaction intermediate exists only transitorily and in a very low concentration on the catalysts.

The adsorption of $\mathrm{CO}_{2}$ and the co-adsorption of $\mathrm{CH}_{4}+\mathrm{CO}_{2}$ on $\mathrm{Re}$ supported by $\mathrm{Al}_{2} \mathrm{O}_{3}, \mathrm{TiO}_{2}, \mathrm{SiO}_{2}$ and $\mathrm{MgO}$ have been investigated by FTIR spectroscopy. The dissociation of $\mathrm{CO}_{2}$ was not experienced on the $\mathrm{Re} / \mathrm{Al}_{2} \mathrm{O}_{3}$ reduced at $673 \mathrm{~K}$, it occurred, however, on the sample reduced at $1073 \mathrm{~K}$.

Addition of $\mathrm{CH}_{4}$ to $\mathrm{CO}_{2}$, initiated the dissociation on all catalysts as indicated by $\mathrm{CO}$ bands at $2041 \mathrm{~cm}^{-1}$. Besides, new spectral features were developed at 1599 and $1397 \mathrm{~cm}^{-1}$ attributed to format species.

No bands due to format were detected on $\mathrm{Re} / \mathrm{SiO}_{2}$ and no format was detected following the co-adsorption of $\mathrm{CO}_{2}$-containing gas mixture on the supporting oxides alone. It was assumed that the format species identified in the surface interactions is located on the support, where it is stabilized. The possible pathways of the occurrence of format complex on the oxides are described.
\end{abstract}

Keywords: co-adsorption, catalyst, support, $\mathrm{CH}_{4}+\mathrm{CO}_{2}$ reaction, formate

\section{INTRODUCTION}

The number of organic chemical products produced in the world moves about 30000 nowdays (WEISSERMEL AND ARPE, 2010). But despite the relatively large numbers, they are just made from a few raw materials. The applied coal is obtained almost exclusively from fossil sources - namely mineral oil, natural gas and hard coal.

The limited resources of coal raised the problem of the exploitation of alternative carbon sources in the early 1970 s.

Carbon dioxide has always enjoyed great attention because of the nature of synthetic building process used successfully during photosynthesis - which can be considered as the basis of life on Earth as well.

In our planet the amount of $\mathrm{CO}_{2}$ and $\mathrm{CO}_{3}{ }^{2-}$ forms are available several times higher than natural resources in the form of hard coal, oil or natural gas form. In addition, this source is virtually limitless, especially if we consider that since the middle of the 19th century at the beginning of industrialization - the amount of "anthropogenic" $\mathrm{CO}_{2}$ has multiplied considerably in the atmosphere. In 1989 the amount of $\mathrm{CO}_{2}$ emission due to industrial activities was approximately $7 \times 10^{9} \mathrm{t}$ (LEITNER, 1995).

Supported $\mathrm{Re}$ is a widely used catalyst in several technologically important reactions, such as the reforming of petroleum feedstock (CIAPETTA AND WALLANCE, 1971).

Re also exhibits oxygen storage properties in automatic three-way catalysts (TAYLOR ET AL., 1984). 


\section{MATERIAL AND METHOD}

Supported rhenium was prepared by impregnating the support in aqueous solution of $\left(\mathrm{NH}_{4}\right)_{2} \mathrm{ReO}_{4} \cdot 4 \mathrm{H}_{2} \mathrm{O}$ (Merck). The following supports were used: $\mathrm{SiO}_{2}(\mathrm{CAB}-\mathrm{O}-\mathrm{SiL}$, and $\mathrm{MS}$ Scintran $\mathrm{BHD}$ ); $\mathrm{Al}_{2} \mathrm{O}_{3}$ (Degussa); $\mathrm{TiO}_{2}$ (Degussa P25) and $\mathrm{MgO}$ (DAB).

After impregnation, the suspensions were dried in air at $383 \mathrm{~K}$. The dried and pulverized samples were pressed into thin self-supporting wafers $\left(30 \mathrm{~mm} \times 10 \mathrm{~mm}, \sim 60 \mathrm{mg} / \mathrm{cm}^{2}\right)$. Further treatment was applied in situ: it consisted of oxidation at $573 \mathrm{~K}\left(100\right.$ Torr of $\mathrm{O}_{2}$ for $30 \mathrm{~min}$ ), evacuation at $573 \mathrm{~K}$ for $30 \mathrm{~min}$, reduction at $673 \mathrm{~K}$ and at $973-1073 \mathrm{~K}$ (100 Torr of $\mathrm{H}_{2}$ for $60 \mathrm{~min}$ ), and evacuation at the temperature of reduction for $30 \mathrm{~min}$.

Note that the heating of the sample from $573 \mathrm{~K}$ to the temperature of reduction was carried out in the presence of hydrogen. As hydrogen can promote the dissociation of $\mathrm{CO}_{2}$, it was absolutely necessary to remove completely the hydrogen from the system after the reduction of $\mathrm{Re}$ catalyst, otherwise the appearance of $\mathrm{CO}$ bands cannot be avoided. The $\mathrm{Re}$ content was $5 \mathrm{wt} \%$ on all samples.

Infrared spectra were recorded with a Digilab. Div. FTS 155 by Biorad with a wave number accuracy of $\pm 4 \mathrm{~cm}^{-1}$. Typically 128 scans were collected. All of the spectra were taken without the use of a scaling factor $(f=1.0)$.

\section{RESULTS}

\section{$\mathrm{CO}_{2}$ adsorption}

The spectra obtained after adsorption of $\mathrm{CO}_{2}$ on $\mathrm{Re} / \mathrm{Al}_{2} \mathrm{O}_{3}\left(\mathrm{~T}_{\mathrm{R}}=673 \mathrm{~K}\right)$ are displayed in Figure $1 A$.

Strong bands appeared at 2334, 1646,1481, 1443 and $1232 \mathrm{~cm}^{-1}$. The intensity of which only slightly decreased after degassing at $300 \mathrm{~K}$.

There were no other spectral features following the adsorption at higher temperatures, 373$673 \mathrm{~K}$. Similar experiment on the $\mathrm{Re} / \mathrm{Al}_{2} \mathrm{O}_{3}$ reduced at $1073 \mathrm{~K}$ produced a weak absorption band at $2040 \mathrm{~cm}^{-1}$, in addition to the previously observed peaks (Figure 1B).

For $\mathrm{Re} / \mathrm{MgO}$, we measured absorption at $\sim 2334,1660-1670,1450,1543,1310$ and 1220 $\mathrm{cm}^{-1}$ at $300 \mathrm{~K}$ (results not shown).

Admission of $\mathrm{CO}_{2}$ on $\mathrm{Re} / \mathrm{TiO}_{2}$ at $300 \mathrm{~K}$ produced bands at $2334,1667,1582,1438,1378$ and $1322 \mathrm{~cm}^{-1}$. The position of which was independent of the temperature in the range of $300-573 \mathrm{~K}$. In the case of $\mathrm{Re} / \mathrm{SiO}_{2}$, we obtained only a band at $2334 \mathrm{~cm}^{-1}$. Evacuation of the cell led to the elimination of the $2334 \mathrm{~cm}^{-1}$ feature in all cases, but did not affect the other bands (results not shown).

The most sensitive method to detect the dissociation of $\mathrm{CO}_{2}$ on supported metals is the FTIR spectroscopy. The spectra presented in Figure 1 clearly show that the dissociation of $\mathrm{CO}_{2}$ is very limited on $\mathrm{Re} / \mathrm{Al}_{2} \mathrm{O}_{3}$. Admission of $\mathrm{CO}_{2}$ on $\mathrm{Re} / \mathrm{Al}_{2} \mathrm{O}_{3}\left(\mathrm{~T}_{\mathrm{R}}=673 \mathrm{~K}\right)$ at $300 \mathrm{~K}$ produced a strong band at $2234 \mathrm{~cm}^{-1}$ due to $\mathrm{CO}_{2}$ and several others at $1646,1481,1443$ and $1233 \mathrm{~cm}^{-1}$ due to carbonate species. Other spectral feature in the $\mathrm{CO}$ stretching region was not seen even after adsorption at $573 \mathrm{~K}$. Evacuation of the cell led to the disappearance of the $\mathrm{CO}_{2}$ band at $2334 \mathrm{~cm}^{-1}$ and did not affect the other bands due to the vibration of carbonates. A CO band at $2040 \mathrm{~cm}^{-1}$ suggesting the dissociation of $\mathrm{CO}_{2}$, however, appeared on highly reduced $\mathrm{Re} / \mathrm{Al}_{2} \mathrm{O}_{3}\left(\mathrm{~T}_{\mathrm{R}}=1073 \mathrm{~K}\right)$. 

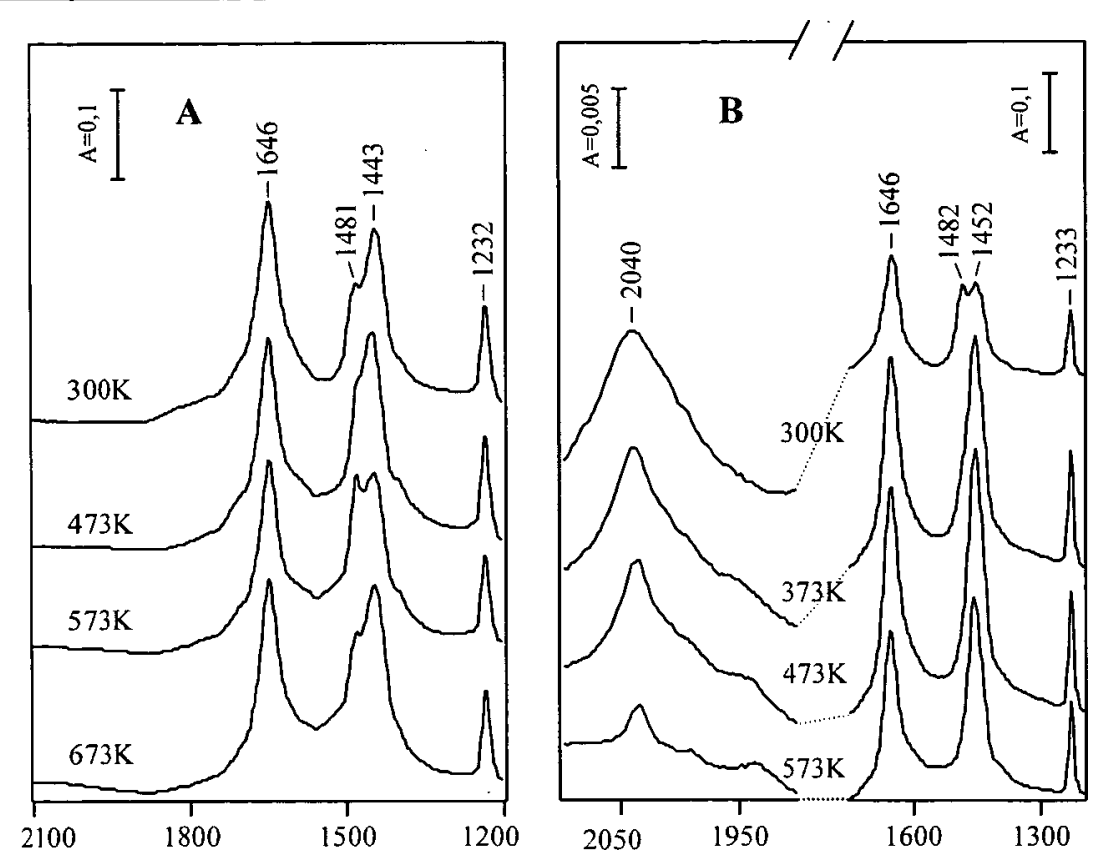

Wavenumber $\left(\mathbf{c m}^{-1}\right)$

Figure 1. FTIR spectra of $\mathrm{Re} / \mathrm{Al}_{2} \mathrm{O}_{3}$ following the adsorption of $\mathrm{CO}_{2}(50$ Torr)

at different temperatures for $15 \min \left(T_{R}=673 \mathrm{~K}\right)$

Reduction temperature: $673 \mathrm{~K}(\mathrm{~A})$ and $1073 \mathrm{~K}(\mathrm{~B})$

\section{$\mathrm{CH}_{4}+\mathrm{CO}_{2}$ adsorption}

Adding methane along with $\mathrm{CO}_{2}$ caused the appearance of $\mathrm{CO}$ band at $2041 \mathrm{~cm}^{-1}$ on $\mathrm{Re} / \mathrm{Al}_{2} \mathrm{O}_{3}$ even at room temperature (Figure $2 A$ ).

The position of the bands in the low frequency region remained unaltered. Raising of the adsorption temperature led to the attenuation of all bands. Weak spectral features were detected at 1599 and $1397 \mathrm{~cm}^{-1}$ following the adsorption at $473 \mathrm{~K}$. These weak spectral features were also detected at $573 \mathrm{~K}$ (not shown). More intense absorption bands were experienced on $\mathrm{Re} / \mathrm{TiO}_{2}$ sample (Figure $2 A$ ).

In addition to the band at $2043 \mathrm{~cm}^{-1}$, weaker peaks appeared at 2009 and $1963 \mathrm{~cm}^{-1}$. On this catalyst a widening of the band at $1583 \mathrm{~cm}^{-1}$ also occurred at higher temperature and a peak at $1557 \mathrm{~cm}^{-1}$ can be distinguished (Figure $2 \mathrm{~A}$ ). Co-adsorption of $\mathrm{CH}_{4}+\mathrm{CO}_{2}$ mixture on $\mathrm{Re} / \mathrm{MgO}$ at $373-473 \mathrm{~K}$ resulted in a formation of a shoulder at $\sim 1580 \mathrm{~cm}^{-1}$ (Figure $2 B$ ). On $\mathrm{Re} / \mathrm{SiO}_{2}$ we obtained only very weak absorption at $1877 \mathrm{~cm}^{-1}$.

Interestingly, the dissociation of $\mathrm{CO}_{2}$ was also facilitated by methane even at $300 \mathrm{~K}$ (Figure 2). The intensity of $\mathrm{CO}$ band was, however, much lower. This is not surprising, if we assume that adsorbed hydrogen is needed for dissociation of $\mathrm{CO}_{2}$. As both $\mathrm{CH}_{4}$ and $\mathrm{CO}_{2}$ adsorb weakly over $\mathrm{Re}$ at $300 \mathrm{~K}$, we can exclude the direct surface interaction between the two adsorbed species. 


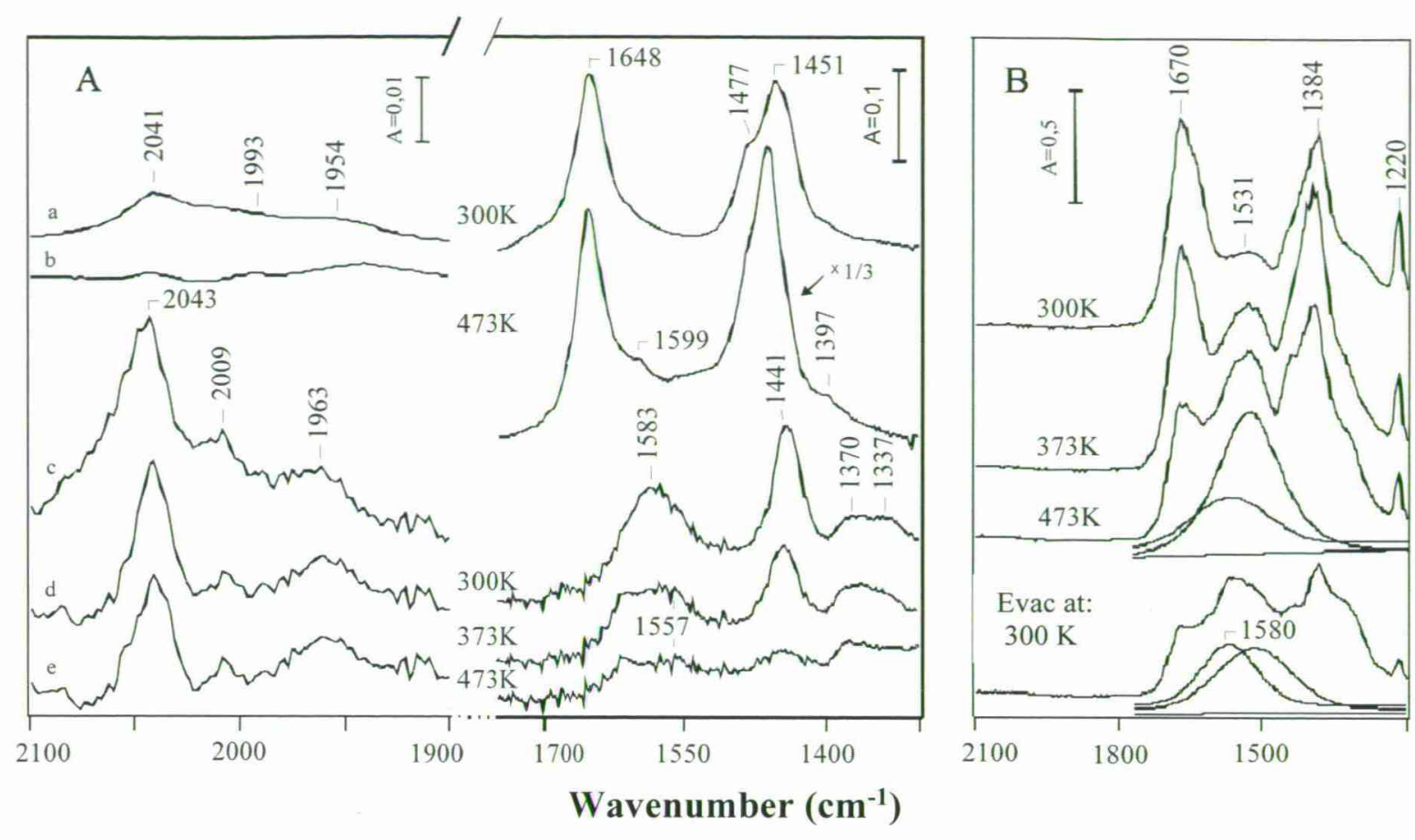

Figure 2. FTIR spectra of Re catalysts following the adsorption of $\mathrm{CH}_{4}+\mathrm{CO}_{2}(1: 1)$ gas mixture at different temperatures for $15 \mathrm{~min}\left(\mathrm{~T}_{\mathrm{R}}=673 \mathrm{~K}\right)$ Supports: (A) $\mathrm{Re} / \mathrm{Al}_{2} \mathrm{O}_{3}$ (a, b); $\mathrm{Re} / \mathrm{TiO}_{2}$ (c-f);

(B) $\mathrm{Re} / \mathrm{MgO}$

\section{CONCLUSIONS}

The adsorption of $\mathrm{CO}_{2}$ on $\mathrm{Re}$ supported by $\mathrm{Al}_{2} \mathrm{O}_{3}, \mathrm{TiO}_{2}, \mathrm{MgO}$ and $\mathrm{SiO}_{2}$ have been investigated by FTIR spectroscopy. The dissociation of $\mathrm{CO}_{2}$ was not experienced on the $\mathrm{Re} / \mathrm{Al}_{2} \mathrm{O}_{3}$ reduced at $673 \mathrm{~K}$, it occurred, however, on the sample reduced at $1073 \mathrm{~K}$.

No format was detected following the co-adsorption of $\mathrm{CO}_{2}$-containing gas mixture on the supporting oxides alone. It was assumed that the format species identified in the surface interactions is located on the support, where it is stabilized.

Addition of $\mathrm{CH}_{4}$ to $\mathrm{CO}_{2}$, initiated the dissociation on all catalysts as indicated by $\mathrm{CO}$ bands at $2041 \mathrm{~cm}^{-1}$. Besides, new spectral features were developed at 1599 and $1397 \mathrm{~cm}^{-1}$ attributed to format species. This assumption was confirmed by the adsorption of $\mathrm{HCOOH}$ vapor on these solids.

\section{REFERENCES}

Ciapetta, F.G., Wallace, D.N. (1971): Catalytic naphtha reforming. Catal. Rev. 5: 67. LEITNER, W. (1995): Carbon dioxide as a raw material: The synthesis of formic acid and its derivatives from CO2. Angew. Chem 34: 2207-2221.

TAYLOR, K.C. (1984): Automobile catalytic converters. In: Anderson, M.J.R., Boudart, M. (Eds.): Catalysis: Science and Technology, 5, Springer Verlag, Berlin. Pp. 120-170.

Weissermel, K., ARPE, H.J. (1997): Industrial organic chemistry, 5th ed. VCH, Weinhem. $525 \mathrm{p}$. 